\title{
Food color and marine turtle feeding behavior: Can blue bait reduce turtle bycatch in commercial fisheries?
}

\author{
Yonat Swimmer ${ }^{1, *}$, Randall Arauz ${ }^{2}$, Ben Higgins ${ }^{3}$, Lianne McNaughton ${ }^{4}$, \\ Marti McCracken ${ }^{1}$, Jorge Ballestero ${ }^{2}$, Richard Brill ${ }^{5}$

\begin{abstract}
${ }^{1}$ National Marine Fisheries Service, Pacific Island Fisheries Science Center, 2570 Dole Street, Honolulu, Hawaii 96822, USA ${ }^{2}$ PRETOMA \& Sea Turtle Restoration Program, 1203-1100 Tibás, San José, Costa Rica

${ }^{3}$ National Marine Fisheries Service, Galveston Sea Turtle Facility, 4700 Avenue U, Galveston, Texas 77551, USA

${ }^{4}$ Joint Institute for Marine and Atmospheric Research, University of Hawaii, 1000 Pope Road, Honolulu, Hawaii 96822, USA

${ }^{5}$ Virginia Institute of Marine Science \& National Marine Fisheries Service, 1208 Greate Road, Gloucester Point,
\end{abstract} \\ Virginia 23062, USA
}

\begin{abstract}
We conducted laboratory and field experiments to investigate the behavioral responses of Kemp's ridley Lepidochelys kempii and loggerhead turtles Caretta caretta to whole squid dyed different colors. Our ultimate goal was to identify bait modifications that could reduce the interaction of turtles with longline fishing gear. In captivity, both turtle species clearly preferred untreated squid over squid that had been dyed dark blue. Loggerhead turtles also preferred untreated squid over reddyed squid, whereas Kemp's ridley showed the opposite response. Field trials of blue-dyed bait were conducted on commercial fishing boats in the Gulf of Papagayo, Costa Rica, where the incidental capture of olive ridley turtles Lepidochelys olivacea is high (long-term average, approximately 7 turtles per 1000 hooks). We found no differences in rates of turtle interactions (8.4 and 8.1 individuals per 1000 hooks) when using untreated versus blue-dyed baits. Although effective in laboratory settings with captive turtles, dyeing bait does not appear to have potential as an effective mitigation measure to reduce sea turtle bycatch in longline fisheries.
\end{abstract}

KEY WORDS: Sea turtle fisheries interactions $\cdot$ Bait color $\cdot$ Sea turtle bycatch mitigation

\section{INTRODUCTION}

The incidental capture of marine turtles in longline fishing gear has been reported to be a significant factor contributing to the current decline of sea turtle populations (Hall et al. 2000, Lewison et al. 2004). Sea turtles most commonly interact with shallow-set $(<100 \mathrm{~m})$ fishing gear that targets swordfish Xiphias gladius, mahi mahi, or dolphin Coryphaena hippurus, or surface-feeding tunas (Ferreira et al. 2001, Polovina et al. 2003). Loggerhead turtles Caretta caretta and olive ridley Lepidochelys olivacea turtles generally bite baited hooks, whereas leatherback turtles Dermo- chelys coriacea are most often hooked in the flippers or become entangled in the fishing lines (Witzell 1999). Despite the fact that both species apparently forage primarily near or at the surface, loggerhead turtles are opportunistic feeders, with a broad range of prey items (Parker et al. 2005), whereas leatherback turtles more specifically target jellyfish (James \& Herman 2001).

Methods to reduce incidental capture of turtles in longline fisheries include area and seasonal closures. While such closures can reduce sea turtle interaction rates, they are not likely to be adopted internationally because of the potential for severe economic disruption (Brothers et al. 1999). Moreover, establishing and 
enforcing marine protected areas on the high seas is not a priority and thus not likely to be adopted by any country with fishing interests. What is urgently needed is a readily exportable solution to the worldwide problem of sea turtles incidentally being captured in longline fishing gear, such as simple gear or bait modification.

A number of operational modifications (e.g. use of streamer lines, underwater line shooters, weights to enhance hook sinking rates, night setting, side setting and use of blue-dyed bait) have been shown to reduce seabird bycatch in longline fisheries (Brothers et al. 1999), while simultaneously maintaining viable fishing operations. Subsequently, numerous fishery management regimes worldwide have adopted seabird mitigation measures. These results served as a model for our studies.

Herein, we present work aimed at identifying a simple mitigation method that could reduce sea turtle interactions with longline fishing gear based on the visual appearance of bait. We chose to investigate the effects of bait color on turtles' feeding behavior, because squid bait dyed dark blue has been shown to significantly reduce seabird interactions in longline fisheries, while simultaneously maintaining acceptably high catch rates of the targeted fish species (McNamara et al. 1999). We also aimed to understand the sensory modalities that sea turtles use to find food sources that attract them to fishing gear and that influence their 'bite/no bite' decision. Specifically, we seek to understand marine turtles' reliance upon olfaction and vision in their food search and feeding behaviors.

\section{MATERIALS AND METHODS}

Captive experiments. We conducted experiments with 49 two yr old loggerhead Caretta caretta and 42 two yr old Kemp's ridley Lepidochelys kempii turtles at the National Marine Fisheries Service Sea Turtle Facility (STF) in Galveston, Texas. The average mass and straight carapace length (SCL) of loggerhead turtles were $11.14 \mathrm{~kg}$ and $45.0 \mathrm{~cm}$, respectively, and those of Kemp's ridley turtles were $5.70 \mathrm{~kg}$ and $33.26 \mathrm{~cm}$, respectively. The loggerhead turtles hatched from approximately 3 to 6 nests on the beach in Clearwater, Florida, on 25 August 1999, and were collected and captive-reared under permits issued by the Florida Fish and Wildlife Conservation Commission (TPNo. 015) and the U.S. Fish \& Wildlife Service (No. TE676379-2). The Kemp's ridleys hatched from approximately 40 nests at Rancho Nuevo, Mexico, on 17 August 2000, and were part of a donation from the Mexican Government to the United States. The Kemp's ridley hatchlings were collected and captive reared under U.S. CITES permit No. US9242929, CITES export permit MEX10941, USFWS TE676379-2, DAN-02768 and Permiso de Pesca de Fomento No. 25.05.00.213.03-1320.

Details of animal husbandry at the STF are described by Higgins (2003). Briefly, turtles were housed individually in suspended cages within large common seawater tanks measuring $6 \mathrm{~m}$ long $\times 2 \mathrm{~m}$ wide $\times 60 \mathrm{~cm}$ deep. The cages holding the loggerheads and Kemp's ridleys measured $90 \times 168 \times 46 \mathrm{~cm}$ deep (rectangular) and $76 \mathrm{~cm}$ diameter $\times 46 \mathrm{~cm}$ deep (round), respectively. Air temperature was regulated at $30^{\circ} \mathrm{C}$, water temperature was between 25 and $30^{\circ} \mathrm{C}$ and salinity was between 14 and 32 ppt. Turtles were fed Purina Aquamax 500 (Purina Mills) grower pellet food at 1 to $3 \%$ body weight $\mathrm{d}^{-1}$, which resulted in maximum growth without overfeeding (Higgins 2003). Prior to behavioral trials, turtles were fasted for approximately $48 \mathrm{~h}$.

To prepare colored baits, frozen squid (Sea Wave Calamari, Monterey Fish Co.) were thawed and marinated overnight in either a $1 \%$ solution of blue-coloring (Food Dye F, D and C No. 1) or a $1 \%$ solution of red-coloring (Food Dye F, D and C No. 40) dye (Virginia Dare).

Behavioral trials were conducted on individual animals in outdoor tanks (4 m diameter and $1.5 \mathrm{~m}$ deep). Tank sides and bottom had been previously painted light blue. Turtles were moved into the tanks and allowed to acclimate for $30 \mathrm{~min}$. Then, 2 dyed and 2 untreated squids ('baits') were presented simultaneously. Baits were suspended from a horizontal plastic rod and were spaced approximately $10 \mathrm{~cm}$ apart. The order of the 4 baits across the rod was randomized by tossing a coin. The baits were submerged, and the order in which baits were eaten was recorded. Trials lasted 30 min after which the turtles were returned to their holding tank. If a turtle did not make a food choice within this time, it was excluded from the analysis. A 'trial' is herein defined as an individual experiment with 1 turtle and 1 'treatment' (e.g. blue- or red-dyed squid).

Individual loggerhead turtles were used 4 times between October 2001 and March 2002 to test for preferences between untreated squid and blue-dyed squid $(\mathrm{n}=49)$. The same individuals were used once during March 2002 to test for preferences between untreated and red-dyed squid ( $\mathrm{n}=42$ ). Experiments with Kemp's ridley turtles $(\mathrm{n}=28)$ were conducted during July and August 2002. There was a minimum of $2 \mathrm{wk}$ between food preference trials.

We investigated turtles' preferences by testing the null hypothesis that turtles would select (as their first choice) both treated (e.g. red- or blue-dyed) squid with the same frequency $(50 \%)$ as untreated squid. Bait selected as the first choice was used to define preference. Binomial tests were conducted for each 


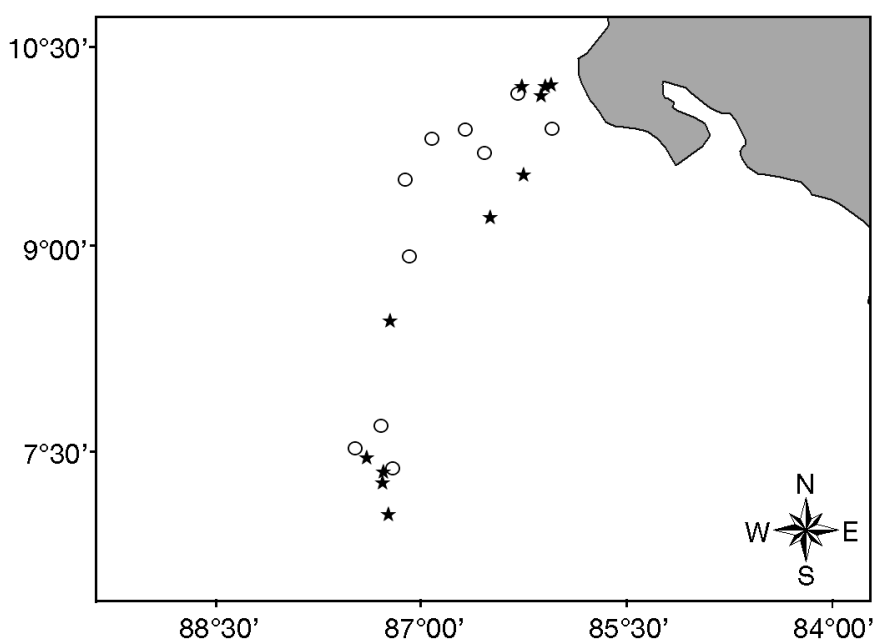

Fig. 1. Location of fishing activities for commercial fishing boats, the 'Don Miguel' ( $\star$ ) and the 'Don Roberto' (O)

dyed food trial using S-Plus V. 6.2 for Windows (Insightful).

Field trials. Experiments to test the efficacy of dyed bait in reducing sea turtle bycatch were conducted on 2 commercial longline fishing boats (length: $\sim 15 \mathrm{~m}$ ), the 'Don Miguel' and the 'Don Roberto', operating out of Playas del Coco in the Gulf of Papagayo, Costa Rica. Trials on both boats were conducted simultaneously from 1 to 15 December 2003. The boats fished as close to each other as feasible in the same general area between $7^{\circ} 00^{\prime} \mathrm{N}, 86^{\circ} 00^{\prime} \mathrm{W}$ and $10^{\circ} 30^{\prime} \mathrm{N}, 88^{\circ} 00^{\prime} \mathrm{W}$ (Fig. 1) and targeted mahi mahi Coryphaena hippurus and tunas Thunnus spp.. Lines were deployed in the morning and remained in the water for approximately $8 \mathrm{~h}$ before haulback in the afternoon. Whole squid Loligo spp. was used exclusively as bait for the first 6 sets on both boats. During sets 7 through 11, muscle strips cut from sailfish Istiophorus platypterus were also used as bait on both boats. Baits were soaked in the same $1 \%$ solution of blue food coloring used in the laboratory trials. The boats made 22 longline sets, 9 with blue-dyed bait and 13 with untreated bait. Sets were randomly alternated between blue-dyed and untreated bait. Size 12/0 circle hooks were used exclusively. The average number of hooks per set was 560 (min. $=452, \max .=675, \mathrm{SD}=82.6)$ for the 'Don Miguel' and 606 for the 'Don Roberto', which included 1 trip in which only 250 hooks were set due to an accident onboard $(\min .=250, \max .=675, \mathrm{SD}=124.8)$. Hooks were relatively shallow given that float and branch lines were approximately 3 to 4 fathoms. Catch rates were standardized to 1000 hooks.

Because of small sample sizes of squid-only baits that were successfully dyed deep blue, only qualitative analyses of the data were performed.

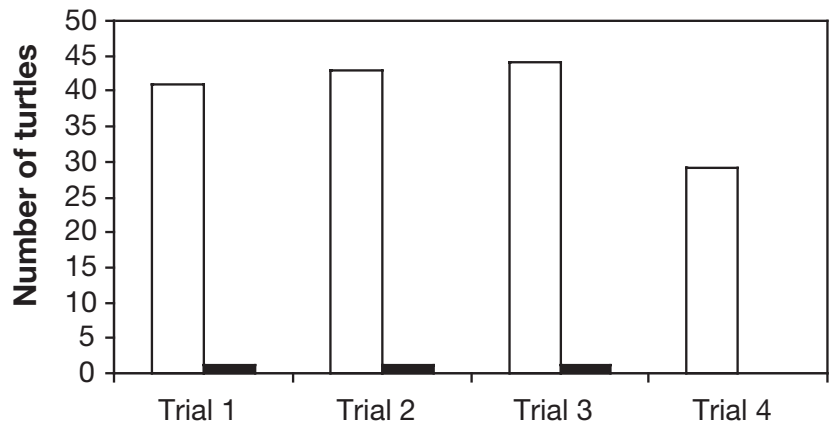

Fig. 2. Caretta caretta. Loggerhead turtles' first choice between untreated (open bars) and blue-dyed squid (black bars) ( $\mathrm{n}=49$ in all 4 trials)

\section{RESULTS}

\section{Captive turtle trials}

Loggerhead turtles Caretta caretta displayed a clear preference for untreated squid when presented with a choice between blue and untreated squid. A total of $98 \%$ of the turtles selected untreated squid over bluedyed squid during each of 4 presentations, which was significantly different from the expected value of $50 \%$ ( $p<0.0001$; Fig. 2). Loggerhead turtles also preferred untreated bait over red-dyed bait ( $p=0.0007$; Fig. 3) during their 1 experimental trial. Kemp's ridley turtles Lepidochelys kempii selected untreated squid over blue-dyed squid at a frequency greater than expected, both for their first and second trials $(\mathrm{p}=0.0225$ and $\mathrm{p}=$ 0.0007, respectively; Fig. 4). In contrast to loggerhead turtles, they selected red-dyed squid over untreated squid with statistically greater frequency during both food trials ( $p<0.02$; Fig. 5).

\section{Field trials}

During both trips, 108 olive ridley turtles Lepidochelys olivacea and 7 green turtles Chelonia mydas

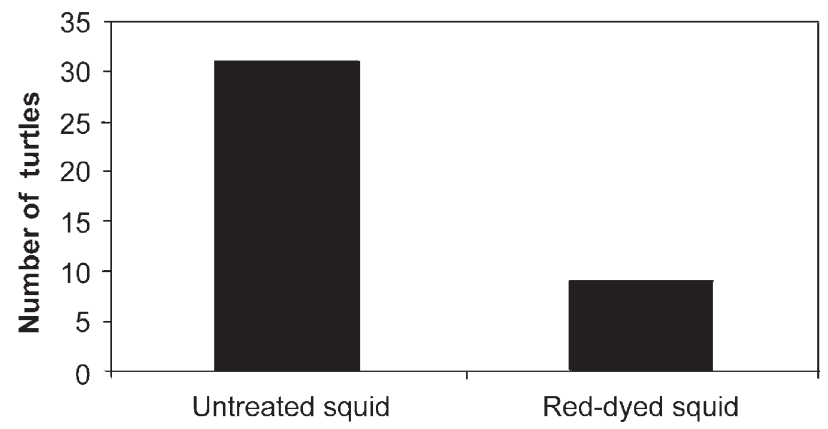

Fig. 3. Caretta caretta. Loggerhead turtles' first choice between untreated and red-dyed squid $(n=42)$ 


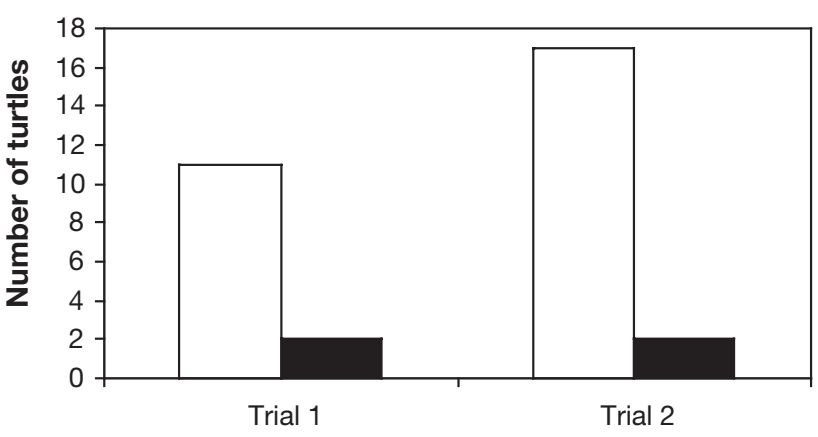

Fig. 4. Lepidochelys kempii. Kemp's ridley turtles' first choice between untreated (open bars) and blue-dyed squid (black bars) ( $\mathrm{n}=42$ in both trials)

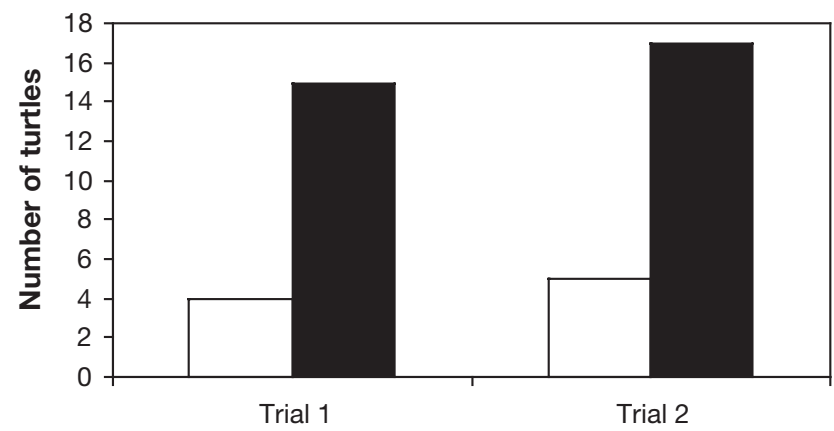

Fig. 5. Lepidochelys kempii. Kemp's ridley turtles' first choice between untreated (open bars) and red-dyed squid (black bars) ( $\mathrm{n}=42$ in both trials)

were caught (Table 1). Because the number of green turtles was relatively small, data on turtle catch rates are combined to include both green and olive ridley turtles. Turtle catch rates were similar for sets made with both blue and untreated bait (8.4 and 8.1 individuals per 1000 hooks, respectively (Table 2).

\section{DISCUSSION}

Our idea was to develop a bait modification that would reduce the incidence of hooking threatened and endangered sea turtles to acceptable levels, but one that would maintain an economically viable catch rate of the targeted species. As an ideal, we also aimed to identify a mitigation measure with demonstrated ability to offer an economic advantage to fishers, thereby increasing its potential use in an unregulated fishery. This could be achieved most readily by decreasing bait loss to unwanted bycatch species and increasing baited hooks available for commercial fish.

Our results clearly show that captive loggerhead and Kemp's ridley turtles base food choice and 'bite/no bite' decisions on color alone and that both species
Table 1. Total catch statistics for fishing vessels 'Don Miguel' and 'Don Roberto' after 11 sets per boat (CPUE: catch per unit effort)

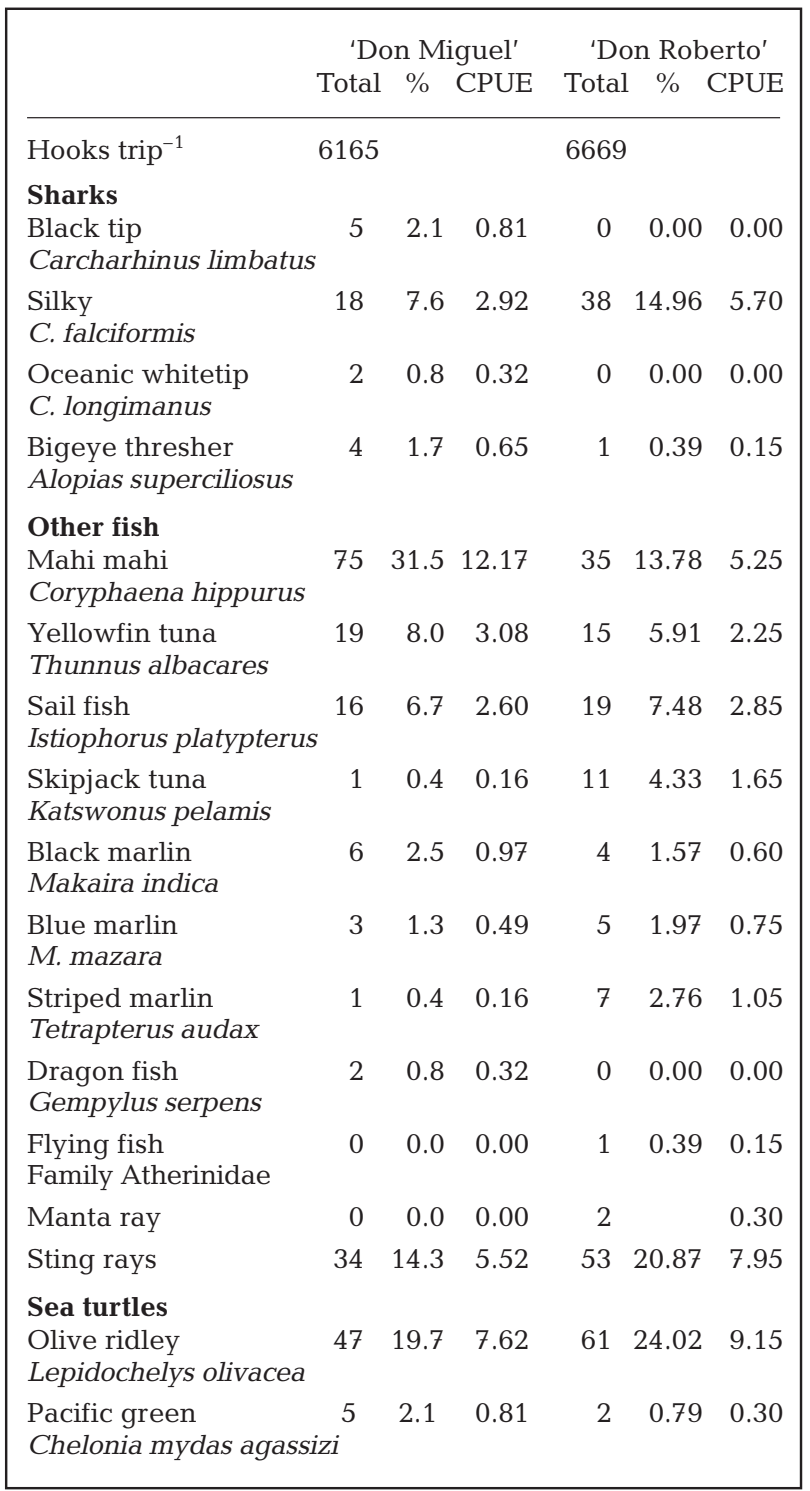

Table 2. Lepidochelys olivacea and Chelonia mydas. Average number of olive ridley and green sea turtles, combined, caught per 1000 longline fishing hooks by the 2 commercial fishing boats after 22 sets in the eastern tropical Pacific Ocean

\begin{tabular}{|cccc|}
\hline Bait type & 'Don Miguel' & 'Don Roberto' & $\begin{array}{c}\text { Combined } \\
\text { average }\end{array}$ \\
\hline Untreated & $\begin{array}{c}7.9 \\
(\mathrm{SE}=3.13 ; \mathrm{n}=6)\end{array}$ & $\begin{array}{c}8.9 \\
\mathrm{SE}=3.14 ; \mathrm{n}=7)\end{array}$ & $\begin{array}{c}8.4 \\
(\mathrm{n}=13)\end{array}$ \\
Blue dye & 8.9 & 7.2 & $\begin{array}{c}8.1 \\
(\mathrm{n}=9)\end{array}$ \\
\hline
\end{tabular}


preferred untreated squid over blue-dyed squid. Previous studies on the responses of captive green turtles Chelonia mydas to foods of various colors found that blue-dyed squids were also significantly less preferred than untreated squid (Swimmer \& Mailloux 2003). Because of our findings that 3 species of sea turtles have an aversion to blue-dyed squid, we designed field trials employing commercial longliners to see if the behaviors of captive turtles could be translated to reduced levels of turtle bycatch. Surprisingly, use of blue-dyed bait in these trials did not result in reduced turtle bycatch.

Dying bait blue can increase catch rates of fish in pelagic fisheries, and the procedure is employed routinely in longline fisheries, despite the fact that no statistical analyses have been conducted (McNamara et al. 1999). Numerous studies have also found that use of blue-dyed bait successfully reduces seabird bycatch in longline fisheries (McNamara et al. 1999), for some species (e.g. albatross species) by as much as $95 \%$, presumably because the dyed bait is more difficult for birds to detect as it reduces the contrast between the bait color and the wavelength of upwelling light. In our studies with captive turtles, however, the dark-bluedyed squids were clearly visible against the light blue walls of the holding tank.

Both behavioral and physiological studies of color vision in various sea turtle species and age classes confirm that they can detect light in the 400 to $700 \mathrm{~nm}$ range (i.e. from blue to red; Fehring 1972, Dvorak \& Granda 1990, Bartol \& Musick 2003). These findings suggest that turtles in our experiments could distinguish blue-dyed squid from untreated squid and that they had an aversion to biting blue-dyed squid. Previous studies also suggest that the sea turtles' ability to distinguish colors is an important component in their foraging ecology (Fehring 1972). It is difficult to interpret the visual differences between the captive turtles' environment within a tank as compared to the perception of bait in the open ocean. In addition to the angle at which the animal looks at the bait, the visibility of objects and colors differs depending on the background light. Thus, an animal looking up at bait towards a bright light would have a different perception of bait color than a turtle looking downward into the dark water. Factors that affect aquatic vision are complex and include the organisms' own visual capabilities, the depth and angle of the viewed object, as well as the optical properties of the water (Johnsen 2002). In the case of sea turtles, recent evidence suggests that young loggerhead turtles can see ultraviolet (UV) light and that they have multiple combinations of color receptors (K. Fritsches pers. comm.), thus enabling them to differentiate shades of colors that appear the same to humans. However, for the open ocean and various depths, the exact light conditions and wavelength discrimination abilities of sea turtles are currently unknown, and thus we assume that objects in turtle tanks do not appear the same as in the open ocean.

Captive loggerhead turtles fed a particular diet have been shown to prefer that diet over time (Grassman \& Owens 1982). Additionally, behavioral studies with green turtles also found that turtles' remembered specific food items (Angermeier \& Hidalgo 1996). In our study, however, the responses of loggerhead and Kemp's ridley turtles to foods of various colors were likely innate responses, as these turtles had been raised since hatching on an artificial diet. Similar preferences for original food items were found for green turtles that had been brought into captivity as large juveniles from their inshore foraging grounds (Swimmer \& Mailloux 2003). These turtles clearly preferred food items that were eaten first while in captivity. Additionally, these turtles $(n=23)$ preferred untreated squid over blue-dyed squid.

During the field trials on commercial longline fishing boats within the Exclusive Economic Zone of Costa Rica, blue-dyed bait did not reduce catch rates of olive ridley or green sea turtles. This was surprising given that longline gear in Costa Rica was set very shallow $(<10 \mathrm{~m})$ and that this visual environment most closely matched the environment of experiments with the captive turtles. Use of blue-dyed squid bait was also found to be ineffective at reducing rates of sea turtle bycatch in the North Atlantic Ocean during field trials conducted on commercial longline fishing vessels over 2 fishing seasons (J. Watson et al. unpubl. data; available at http://www.mslabs.noaa.gov/mslabs/docs/ pubs.html). Additional experiments were conducted to determine the catch rates of targeted swordfish using fishing gear designed to be less detectable to turtles in the North Pacific Ocean. In order to achieve 'stealth' gear, floats were counter shaded, lines were blue, hardware (e.g. snaps) was dulled, LED light sticks faced downward and blue-dyed squid baits were used exclusively. As a result, however, significantly fewer (30\% reduction) swordfish were caught as compared to controls. This study was not designed to detect any effect on sea turtle captures because the expected (and observed) number of turtles captured was too few (Boggs 2003).

Our results with marine turtles in captivity demonstrate the importance of color in the turtles' decision to bite bait. Additionally use of blue bait has been an effective mitigation measure to reduce seabird bycatch. Results presented herein and in other studies, however, suggest that dying bait blue is not effective in reducing sea turtle bycatch. Thus, we do not believe that further investigations regarding use of blue bait to reduce sea turtle bycatch are warranted. Because less- 
preferred bait color apparently does not deter sea turtles from biting baited longline gear in the open ocean, our results suggest that turtles use a combination of both vision and other sensory stimuli (e.g. olfaction/ gestation, acoustic) in detecting baited fishing gear. Recent research examining loggerhead turtles' use of olfactory cues in detecting food (A. L. Southwood pers. comm.) could be incorporated with behavioral and physiological studies on turtle vision to identify an effective mitigation measure to reduce sea turtle bycatch. We encourage future researchers in the area of sea turtle bycatch reduction to combine aspects of sea turtles' chemosensory capabilities.

Acknowledgements. We gratefully acknowledge the assistance of many hard-working fishermen, biologists and administrators involved with various aspects of this research. We thank Drs. M. Laurs and C. Boggs for supporting pilot studies at the NOAA Fisheries Honolulu Laboratory, Kewalo Basin Facility, in Honolulu, Hawaii. We thank J. Sibert of the Pelagic Fisheries Research Program for financial support of the field trials. At the NOAA Sea Turtle Facility in Galveston, Texas, we received invaluable help with captive turtles from C. Bustinza, M. Rodriguez and S. Kethan. We also thank Dr. R. Zimmermen, C. T. Fontaine and D. Revera, who provided access to turtles within the facility. We appreciate the valuable contributions of 3 anonymous reviewers. We thank J. Kendig and Drs. A. L. Southwood and M. Chaloupka for helpful editorial comments. All research was conducted with the approval of the University of Hawaii Animal Care and Use Committee (protocol No. 02-046-2).

\section{LITERATURE CITED}

Angermeier WF, Hidalgo ARS (1996) Food-rewarded operant learning and memory in the East Pacific green turtle. Mar Turtle Newsl 75:4-6

Bartol S, Musick J (2003) Sensory biology of sea turtles. In: Lutz PL, Musick JA, Wyneken J (eds) The biology of sea turtles, Vol 2. CRC Press, Boca Raton, FL, p 79-102

Boggs C (2003) Fishing experiments on sea turtle bycatch. In: Long KJ, Schroeder BA (eds) Proceedings of the International Technical Expert Workshop on Marine Turtle Bycatch in Longline Fisheries. US Dept of Commerce,

Editorial responsibility: Kenneth Sherman, (Contributing Editor), Narragansett, Rhode Island, USA
NOAA Technical Memorandum NMFS-F/OPR-26

Brothers NP, Cooper J, Lokkeborg S (1999) The incidental catch of seabirds in longline fisheries: worldwide review and technical guidelines for mitigation. FAO Fish Circ 937:1-100

Dvorak CA, Granda AM (1990) Wavelength dependent temporal properties of retinal horizonta cells in turtles. Vis Neurosci 4:427-435

Fehring WK (1972) Hue discrimination in hatchling loggerhead turtles (Caretta caretta). Anim Behav 20:632-636

Ferreira RL, Martins HR, Silva AA, Bolten AB (2001) Impact of swordfish fisheries on sea turtles in the Azores. Life Mar Sci A 18:75-79

Grassman MA, Owens DW (1982) Development and extinction of food preferences in the loggerhead sea turtle (Caretta caretta). Copeia 4:965-969

Hall MA, Alverson DL, Metuzals KI (2000) By-catch: problems and solutions. Mar Pollut Bull 41:204-219

Higgins BM (2003) Sea turtle husbandry. In: Lutz PL, Musick JA, Wyneken J (eds) The biology of sea turtles, Vol 2. CRC Press, Boca Raton, FL, p 411-440

James MC, Herman TB (2001) Feeding of Dermochelys coriacea on medusae in the northwest Atlantic. Chelonian Conserv Biol 4(1):202-205

Johnsen S (2002) Cryptic and conspicuous coloration in the pelagic environment. Proc R Soc Lond (Biol) 269:243-256

Lewison RL, Freeman SA, Crowder LB (2004) Quantifying the effects of fisheries on threatened species: the impact of pelagic longlines on loggerhead and leatherback sea turtles. Ecol Lett 7:221-231

McNamara B, Torre L, Kaaialii G (1999) Hawaii longline seabird mortality mitigation project. Western Pacific Fisheries Management Council, Honolulu, HI

Parker DM, Cooke WJ, Balazs GH (2005) Diet of oceanic loggerhead sea turtles (Caretta caretta) in the central North Pacific. Fish Bull (Wash DC) 103:142-152

Polovina JJ, Howell E, Parker DM, Balazs GH (2003) Divedepth distribution of loggerhead (Caretta caretta) and olive ridley (Lepidochelys olivacea) sea turtles in the central North Pacific: might deep longline sets catch fewer turtles? Fish Bull (Wash DC) 101(1):189-193

Swimmer Y, Mailloux L (2003) Bait modification research: reducing incidental interactions between sea turtles and longline fishing gear. In: Proceedings of the 54th annual tuna conference, May 13-16, 2003, Lake Arrowhead, CA

Witzell W (1999) Distribution and relative abundance of sea turtles caught incidentally by the U.S. pelagic longline fleet in the Western North Atlantic Ocean, 1992-1995. Fish Bull (Wash DC) 97:200-211

Submitted: October 14, 2004; Accepted: February 18, 2005 Proofs received from author(s): June 9, 2005 